\title{
Cu(I)-Mediated Alkyl Group Transfer of Alkylboranes to Carboxylic Acid Chlorides
}

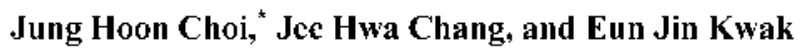 \\ Department of Chemistr: Hanyang University: Seoul 133-791, Korea \\ Recened January 15, 2004
}

Key Words : Alkylborane, Carboxylic acid chloride, Alkyl group transfer, Copper(I) iodide

The alkyl group transler reaction of alkylboranes with carboxylic acid chlorides affords the cortesponding ketones in moderate yiclds in the presence of potassium tertbutoxide and copper(I) iodide.

We reported previously that the electrochemical alkyl group transfers from trialkylboranes to carbonyl compounds, carboxylic acid compounds ${ }^{2}$ and epoxide compounds by implementing an electrochentical procedure using copper as a sacrilicial anode in an undivided cell. $\Lambda$ s soon as it was published, this method drew great attention because of its enormous potential in synthetic utility. ${ }^{4}$ Therefore, based on this method, we examined the alkyl group transfer reaction of alkylboranes with carboxylic acid chlorides by the electrochemical procedure ${ }^{2}$ and also by the general organic chemistry procedure.

Now, we report a new methodology lor the alkyl group transler reaction of alkylboranes with carboxylic acid chlorides via the reactive copper(I) alkylborate complexes in the presence of potassium tert-butoxide and copper(I) iodide by a mild organic chemistry process. Although alkylmagnesium, -zinc, -lin. and aluminum reagents have been successlully used for alkyl transfer reactions with acid chloride, ${ }^{5}$ the result comprises an excellent carbon-carbon bond formation synthesis since alkylboranes are readily prepared by hydroboration from alkenes, unlike alkyl transler reactions reported by Suzuki et $a .^{\circ} \wedge$ nd this reaction was also successful in carbon-carbon bond formation

Table 1. Oplimization of organyl group transfer reaction condition of triethylborane to octanoy: chloride"

\begin{tabular}{|c|c|c|c|c|c|}
\hline entry & solvent & $\begin{array}{l}\text { copper(I) } \\
\text { halide }\end{array}$ & bast & $\begin{array}{l}\text { reaction } \\
\text { time (h) }\end{array}$ & $\begin{array}{l}\text { yield } \\
(\%)^{h}\end{array}$ \\
\hline 1 & THIF-IIMPA(2:1) & Cull & $\mathrm{KOC}\left(\mathrm{CH}_{3}\right)_{3}$ & 4 & 63 \\
\hline 2 & THIF-IIMPA $(5: 1)$ & Cul & $\mathrm{KOC}\left(\mathrm{CH}_{3}\right)_{3}$ & 14 & 44 \\
\hline 3 & THII-IIMPA(1:1) & Cull & $\mathrm{KOC}\left(\mathrm{CH}_{3}\right)_{3}$ & 15 & 27 \\
\hline 4 & TllF" & Cull & $\mathrm{KOC}\left(\mathrm{CH}_{3}\right)_{3}$ & 14 & 39 \\
\hline 5 & TIII-I)MI:(2:1) & Cul & $\mathrm{KOC}\left(\mathrm{CH}_{3}\right)_{3}$ & 14 & 27 \\
\hline 6 & IFII:-IMPA $(2: 1)$ & CuBr & $\mathrm{KOC}\left(\mathrm{CH}_{3}\right)_{3}$ & 4 & 54 \\
\hline 7 & THIV-IIMPA $(2: 1)$ & Cucl & $\mathrm{KOC}\left(\mathrm{CH}_{3}\right)_{3}$ & 6 & 29 \\
\hline 8 & THIF-IIMPA(2:1) & - & $\mathrm{KOC}\left(\mathrm{CH}_{3}\right)_{3}$ & 14 & no reaction \\
\hline 9 & THIF-IMPA(2:1) & Cull & $\mathrm{NaOCH}_{3}$ & 14 & 3 \\
\hline 10 & THIF-IIMPA(2:1) & Cull & $\mathrm{NaCOCl} \mathrm{C}_{2} \mathrm{CH}_{3}$ & 14 & trace \\
\hline
\end{tabular}

"Reactions of octanoyl clloride $(10$ mmole) with triethylborane 15 mmole) were carried out using potassium tert-butoxide (1 cq.) and copper(I) halides (1 eq.) at room temperature. "Isolated yiclds are based on triethylborane without expensive palladium catalysts.

First of all, a varicty of solvents, such as tetrahydrofuran (T][F) - hexamethylphosphoric triamide (][MPA) (1:1, $2: 1,5: 1)$, telrahydrofuran (TIF) - dimethylformamide (DMF) (2:1), and tetrahydrofuran (THF) as a solvent, copper(l) halides, such as copper(I) bromide, copper(I) iodide, and copper(l) chloride, and bases, such as potassium tert-butoxide, sodium methoxide, and sodium ethoxide were examined to find the combination that affords the best yicld.

$\Lambda$ s a result, we found that TH IF-IIMPA $(2: 1)$ as a solvent, copper(l) iodide as a copper(I) halide, and potassium tertbutoxide as a base gave the best yicld (Table 1).

$\Lambda$ s shown in Table 1, the ethyl group transler reaction of triethylborane was especially affected not by sodium methoxide (entry 9) and sodium ethoxide (entry 10) but by potassium tert-butoxide (entry 1). Also copper(I) halides

Table 2. The alkyl Iransler of various alkylboranes to various uarboxylic acid chlorides in the presence of potassium tert-butoxide and copper(l) iodider

\begin{tabular}{|c|c|c|c|c|}
\hline entry & substrate & borane & $\begin{array}{l}\text { addilive } \\
\text { compound }\end{array}$ & $\begin{array}{l}\text { yield } \\
(\%)^{c}\end{array}$ \\
\hline 1 & $\mathrm{CH}_{3}\left(\mathrm{CH}_{2}\right)_{0} \mathrm{COCl}$ & $\left(\mathrm{CH}_{3} \mathrm{CH}_{2}\right)_{3} \mathrm{~B}$ & - & 63 \\
\hline 2 & $\left.\mathrm{Br}\left(\mathrm{CH}_{2}\right), \mathrm{COC}\right]$ & $\left(\mathrm{CH} ; \mathrm{CH}_{2}\right)_{i \mathrm{~B}} \mathrm{~B}$ & - & 53 \\
\hline 3 & & $\left(\mathrm{CH}_{3} \mathrm{CH}_{2}\right)_{i} \mathrm{~B}$ & - & 68 \\
\hline 4 & & $\left(\mathrm{Cl}_{3} \mathrm{C}_{2} \mathrm{Cl}_{2} \mathrm{Cl}_{2} \mathrm{Cl}_{2}\right)_{3} \mathrm{l} 3$ & I'ME:I)A & 6.3 \\
\hline 5 & & $\left(\mathrm{CH}_{3} \mathrm{CH}_{2}\right)_{i} \mathrm{~B}$ & TMEDA & 64 \\
\hline 6 & & $\left(\mathrm{CH}_{3} \mathrm{CH}_{2}\right)_{3} \mathrm{~B}$ & TME:IDA & 68 \\
\hline $7^{i t}$ & $\mathrm{CH}_{3}\left(\mathrm{CH}_{2}\right)_{6} \mathrm{COCl}$ & & - & 44 \\
\hline $8^{d}$ & & & - & 59 \\
\hline
\end{tabular}

"Reactions of carboxylic acid chlorides ( 10 mmole) with alkylburames (5 mmole) were carried out in $1 \mathrm{HF}^{\prime}$ : $\mathrm{HMI}^{2} \mathrm{~A}(2: 1)$ of solvent by using potassium tert-butoside ( 1 eq.) and coppertl) halides (l eq.) "[solated yiclds are based on alkylboranes. ' 2 eq additive compound TMF. DA was utilized. "Ilydroboration ol dicyclohexene and 9-BBN" and l-hexene were arried out by moditying the literature procedure. 
played an important role in successfully achieving ethyl group transfer reaction of triethylborane (entries 1. 6.7. and 8).

Finally, to evaluate the alkyl group transfer reaction various caroxylic acid chlorides and a variety of organoboron compounds were evaluated under our standard condition [THF-HMPA $(2 ; 1)$, copper(I) iodide, and potassium tertbutoxide]. The results of the alkyl transfer reaction are summarized in Table 2 .

When the alkyl groups transfer reaction of trialkylboranes was conducted with the alipatic carboxylic acid chlorides octanoyl chloride, 5-bromo-valeroyl chloride. and cyclohexa carbonyl chloride. and the aromatic carboxylic chlorides benzoyl chloride, 4-methyl benzoyl chloride, and 4-bromobenzoyl chloride. the desired ketones were obtained in the yield range of $63-53 \%$ in th (entries 1-6). In contrast, when B-hexyl-dicyclohexylborane and B-hexyl-9-BBN were used as a alky lboranes to a hexyl group transfer reaction. yields more or less decreased (entries 7, 8). Futhermore, aromatic acid chlorides. such as benzoyl chloride (entry 4), 4-methyl benzoyl chloride (entry 6), and 4-bromo benzoyl chloride (entry 5), generated the corresponding ketones more successfully when an additive compound. TMEDA, was added to the reaction ressel.

In view of the results so far achieved. the experiments show no distinguishable differences in reaction rate for any structural change for both alkylboranes and substrates. Moreover, despite the absence of any systematic study to fund out the mechanism, the most probable mechanism of alkyl transfer reaction involves the nucleophilic addition of alkyl anions which are generated from allylboranes in the presence of potassium tert-butoxide and copper(I) iodide.

We have found that the reactive copper alkylborate complexes generated from alkylboranes easily undergo alkyl group transfer reaction to carboxylic acid chlorides in moderate yields under a mild condition. Further studies of the mechanism and scope of this reaction are in progress. A detailed study of the scope and limitations of the synthesis is also in progress.

\section{Experimental Section}

General Method. All reactions were performed in flame or oven dried glassware under a positive nitrogen pressure. Air and moisture sensitive compounds were introduced through a syringe or cannula through a nubber septum. Compounds 9-BBN (1 M.THF), potassium tert-butoxide. and copper(I) halides were purchased from Aldrich. Hydroborations were prepared according to or by modifying documented procedures. Products were consistent with the documented reports. THF was distilled from sodium/ benzophenone kethyl under a nitrogen atmosphere. Analytical thin-layer chromatography was performed with E. Merck silica gel $60 \mathrm{~F}$ glass plates and flash chromatography using $\mathrm{E}$. Merck silica gel 60 (230-400 mesh). ${ }^{1} \mathrm{H}$ spectra were recorded on a Varian Unit Inova 400 spectrometer. All NMR data were obtained in $\mathrm{CDCl}_{3}$ solution. chemical shifts $(\delta)$ are given in ppm relative to TMS.
Typical Experimental Procedure. $10 \mathrm{~mL}$ of triethylborane (1 M. $10 \mathrm{mmole}$ ) was placed in $100 \mathrm{~mL}$ flask. Potassium tert-butoxide (1.22 g. 10 mmole), $10 \mathrm{~mL}$ of THF, and $5 \mathrm{~mL}$ of HMPA were added to the flask under a nitrogen atmosphere and stirred at room temperature for $30 \mathrm{~min}$. Copper iodide ( $1.90 \mathrm{~g} .10 \mathrm{mmole}$ ) was added to the reaction mixture which was then stirred for $30 \mathrm{~min}$. After the color changing to dark blue-black, octanoyl chloride $(3.4 \mathrm{~mL} .20$ mmole) was added to the reactants which were then stirred again at room temperature for $4 \mathrm{~h}$. The products were isolated in the following manner. The reactants were quenched with $50 \mathrm{~mL}$ of water and the product extracted in $n$-hexane $(3 \times 20 \mathrm{~mL})$. The combined organic extracts ware dried over anhydrous magnesium sulfate before solvent removal under reduced pressure. The product was purified by column chromatography (hexane $:$ ethyl acetate $:$ ether $=$ $30: 1: 1)$ to yield $0.98 \mathrm{~g}(63 \%)$ of the desired decan-3-one. Other products followed the same procedure. ${ }^{1} \mathrm{H}$ NMR $\left(\mathrm{CDCl}_{3}\right) \delta 2.4(\mathrm{t}, J=7.6 \mathrm{~Hz} .4 \mathrm{H}), 1.6-1.5(\mathrm{t}, J=6.8 \mathrm{~Hz} .2 \mathrm{H})$, $1.1=1.0(\mathrm{t}, J=7.2 \mathrm{~Hz}, 3 \mathrm{H}), 1.3(\mathrm{~m} .8 \mathrm{H}) .0 .9(\mathrm{t}, J=6.8 \mathrm{~Hz} .3 \mathrm{H})$.

6-Bromo-hexan-3-one: The product was isolated by flash chromatography (hexane : ethyl acetate : ether $=100: 1: 1$ ) to give $0.94 \mathrm{~g}(53 \%){ }^{1} \mathrm{H} \mathrm{NMR}\left(\mathrm{CDCl}_{3}\right) \delta 3.4(\mathrm{t}, J=6.6 \mathrm{~Hz}$, $2 \mathrm{H}) .2 .4(\mathrm{~m}, 4 \mathrm{H}), 1.9(\mathrm{~m} .2 \mathrm{H}) .1 .7(\mathrm{~m}, 2 \mathrm{H}), 1.1(\mathrm{t}, J=7.2 \mathrm{~Hz}$. $3 \mathrm{H})$.

1-Cyclohexyl-propane-1-one: The product was isolated by flash chromatography (hexane : ethyl acetate : ether $=30$ : $\mathrm{l}: \mathrm{l})$ to give $\left.0.95 \mathrm{~g}(68 \%)^{1} \mathrm{H} \mathrm{NMR}(\mathrm{CDCl})_{3}\right) \delta 2.5$ (q. $J=7.2$ Hz. $2 \mathrm{H}) .2 .3(\mathrm{~m} . \mathrm{HH}) .1 .9(\mathrm{~m}, 4 \mathrm{H}) .1 .4-1.2(\mathrm{~m}, 6 \mathrm{H}), 1.0(\mathrm{t}, J$ $=7.2 \mathrm{~Hz} \cdot 3 \mathrm{H}$ ).

Tetradecan-3-one: The product was isolated by flash chromatography (hexane : ethyl acetate : ether $=30: 1: 1$ ) to give $0.93 \mathrm{~g}(44 \%){ }^{1} \mathrm{H}$ NMR $\left(\mathrm{CDCl}_{3}\right) \delta 2.4(\mathrm{~m}, 4 \mathrm{H}) .1 .9(\mathrm{~m}$. $2 \mathrm{H}) .1 .6(\mathrm{~m}, 4 \mathrm{H}) .1 .4-1.2(\mathrm{~m} .14 \mathrm{H}) .0 .9(\mathrm{~m}, 3 \mathrm{H})$.

Phentanophenone: The product was isolated by flash chromatograply (hexane : etlyyl acetate $=8: 1$ ) to give 1.02 $\mathrm{g}(63 \%){ }^{~} \mathrm{H}$ NMR $\left(\mathrm{CDCl}_{3}\right) \delta 7.95(\mathrm{~d}, J=6.8 \mathrm{~Hz} .2 \mathrm{H}), 7.55$ (m. IH). $7.46(\mathrm{~m}, 2 \mathrm{H}), 2.97$ (t. $J=7.2 \mathrm{~Hz}, 2 \mathrm{H}), 1.4 \mathrm{l}(\mathrm{m}, 2 \mathrm{H})$, $0.95(\mathrm{t} . J=7.6 \mathrm{~Hz}, 3 \mathrm{H})$.

4-Methyl propiophenone: The product was isolated by flash chromatography (hexane : ethyl acetate $=8: 1$ ) to give $1.02 \mathrm{~g}(68 \%){ }^{l} \mathrm{H} \mathrm{NMR}\left(\mathrm{CDCl}_{3}\right) \delta 7.86(\mathrm{~d} . J=8.0 \mathrm{~Hz}, 2 \mathrm{H})$. 7.24 (d. $J=8.0 \mathrm{~Hz} .2 \mathrm{H}$ ). 2.97 (q. $J=7.2 \mathrm{~Hz}, 2 \mathrm{H}$ ). 2.93 (s. $3 \mathrm{H}) .1 .21(\mathrm{t} . J=7.6 \mathrm{~Hz}, 3 \mathrm{H})$.

+Bromo propiophenone: The product was isolated by flash chromatography (hexane : ethyl acetate $=4: 1$ ) to give $1.36 \mathrm{~g}(64 \%){ }^{l} \mathrm{H}$ NMR $\left(\mathrm{CDCl}_{3}\right) \delta 7.93(\mathrm{~d} . J=8.4 \mathrm{~Hz}, 2 \mathrm{H})$, 7.60 (d. $J=8.4 \mathrm{~Hz}, 2 \mathrm{H}) .2 .98(\mathrm{q} . J=7.6 \mathrm{~Hz} .2 \mathrm{H}) .1 .22(\mathrm{t} . J=$ $7.2 \mathrm{~Hz} .3 \mathrm{H})$.

Acknowledgment. This work was supported by Korea Research Foundation Grant (KRF-2001-015-DPO337).

\section{References}

1. (a) Choi. J. H.: Youmn. J. S.: Cho. C. G.: Czae. M. Z.: Hwang. B. K.: Kim. J. S. Tetrohedon Lett. 1998. 39. 4835. (b) Choi. J. H.: 
Youm, I. S.: Cho. C. G.: Czwa, M. Z.: Hwang B. K.: Kim, I. S. Bull. Konam them Soc. 1998. 19.805.

2. Choi. J. H.: Cho. S. W.: Kim. B. S. Bull Korean Chem. Soc. 1999. 20.989

3. Choi, I. H.: Lee. S. I. Joo. C. R: Kim. J. S: Baek. D. J. Bull. Konean Chem. Soc. 1999. 20,1384.

4. Choi, J. H.: Youm. I. S.: Cho. C. G.: Czae, M. Z: Hwang. B. K.: Kim. J. S. (Chemtech (mark. 1999. page 4) as "heart cut"

5. (a) Miyaura. N.: Itoh. M.: Suzuki. A.: Brown. H. C.: Midland. M. M.: Jacob. P. III J Am. Chem. Soc. 1972. 94. 6549. (b) Okada. K.:
Hosoda. Y.: Oda, M. Tetrahedron Lett. 1986, 27, 6213. (c) Mikhailov. B. M.: Baryshnikova. T. K.: Shashlov. A. S. $J$. Organontet. Chent 1981.219.301.

6. (a) Miyaura. N.: Ishiyama. T.: Sasaki. H.: Ishikawa. M.: Sato. M. Suzuki. A. J. An Chem. Soc. 1989, 111. 314. (b) Hoshino, Y: Ishivama. T.: Mivaura, N.: Suzuki, A. Tetrahedron Lett. 1988. 29. 3983. (c) Ishiyama. T, Mivaura. N.: Suzuki. A. Tetrahedron Lett 1991. 32. 6923. (d) Miyaura. N.: Ishikawa. N.: Suzuki. A Tetrahedon Lett. 1992. 33. 2571. (e) Ishiyama. T.: Abe. S. Miyaura. N.: Suzuki. A. Chem. Letf. 1992.691. 